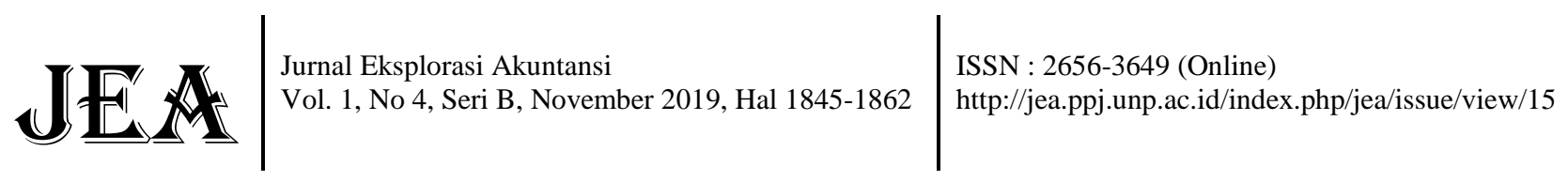

\section{FAKTOR FAKTOR YANG MEMPENGARUHI MAHASISWA DALAM PEMILIHAN KARIR MENJADI AUDITOR PADA INSTANSI PEMERINTAH DAN SWASTA}

\section{(Studi Empiris pada Mahasiswa Akuntansi Angkatan 2015-2016 Perguruan Tinggi Negeri dan swasta se-Indonesia)}

\author{
Sutan Pandilon ${ }^{1}$, Charoline Cheisviyanny ${ }^{2}$ \\ ${ }^{1}$ Alumni Jurusan Akuntansi Fakultas Ekonomi, Universitas Negeri Padang \\ ${ }^{2}$ Jurusan Akuntansi Fakultas Ekonomi, Universitas Negeri Padang \\ *Korespondensi: sutanfandilon@ gmail.com
}

\begin{abstract}
This study aims to analyze the factors which influence accounting students in choosing accounting career as auditor at both private and government instutions. The factors are financial reward, work environment, labor market consideration, social values, professional recognition, family environment, and personality. The population in this study is accounting students in state and private university of Indonesia. The sample is determined based on the non-probability sampling method. The data used in this study are primary data. This study used a questionnaire 177 respondents. The method of analysis is multiple linear regression analysis. The results showed that work environment, social values, professional recognition, and family environment have no significant effect on career selection as auditor. While the financial reward, labor market consideration, and personality have a positive significant effect on career selection as an auditor.
\end{abstract}

Keywords: career, auditor, accounting students, universities

\section{How to cite (APA $6^{\text {th }}$ style)}

Pandilon, S. \& Cheisviyanny, C. (2019). Faktor-Faktor yang Mempengaruhi Mahasiswa dalam pemilihan karir menjadi auditor pada instansi pemerintah dan swasta (Studi Empiris pada Mahasiswa Akuntansi Angkatan 2015-2016 Perguruan Tinggi Negeri dan Swasta SeIndonesia). Jurnal Eksplorasi Akuntansi, 1(4), Seri B, 1845-1862.

\section{PENDAHULUAN}

Umumnya setiap manusia atau individu mempunyai keinginan dalam mencapai semua sesuatu atau keadaan yang telah dicita-citakannya baik itu keinginan dari pribadinya maupun dorongan dari pihak keluarga dalam menentukan karirnya. Seiring dengan pesatnya perkembangan dunia usaha khususnya di Indonesia, seperti tumbuhnya lembaga keuangan baik bank maupun non bank serta pasar modal dan adanya perusahaan-perusahaan yang bergerak dalam bidang bermacam industri di Indonesia. Dalam hal ini, pendidikan akuntansi harus selalu didukung agar dapat menghasilkan lulusan sarjana yang berkualitas dan masing-masing mahasiswa dapat memilih karir yang baikyang siap untuk bersaing di dalm dunia kerja. 
Dalam pemilihan karir dan pekerjaan untuk para sarjana akuntansi, terdapat beberapa profesi yang dapat dipilih oleh sarjana akuntansi, salah satunya profesi sebagai auditor. Auditor merupakan profesi akuntansi yang selalu berkaitan dengan penyediaan jasa audit atau pemeriksaan keuangan. Dalam melaksanakan audit, auditor mengkaji ulang terhadap laporan keuangan historis kliennya dan memberikan opini profesional mengenai kewajiban penyajian laporan keuangan tersebut. Selain itu, profesi auditor ini juga sangat memberikan banyak peluang dalam mendapatkan segala pekerjaan yang menantang dan beragam karena dapat ditempatkan dibeberapa lokasi maupun daerahdi berbagai perusahaan yang memiliki ciri dan kondisinya yang berbeda.

Profesi Auditor di Indonesia dibagi berdasarkan fungsi dan instansi tempat mereka bekerja. Penelitian ini berfokus kepada pilihan karir sebagai auditor baik auditor pemerintah, auditor kap, dan auditor internal. Auditor pemerintah mempunyai tugas menilai kewajaran informasi laporan keuangan pemerintah atas pelaksanaan program dan penggunaan aset milik negara. Audit instansi pemerintah pada umunya dilaksanaan oleh Badan Pemeriksaan Keuangan (BPK) sebagai auditor eksteral pemerintah, serta Badan Pengawasan Keuangan dan Pembangunan (BPKP) dan Inspektorat sebagai auditor internal pemerintah.

Dalam menentukan karir sebagai auditor, mahasiswa akuntansi sering dijumpai terdapat berbagai kepastian dan beberapa faktor-faktor yang mempengaruhi minat mahasiswa dalam berkarir. Rahayu, dkk (2003) menyatakan bahwa pemilihan karir dapat dipengaruhi oleh beberapa faktor yaitu penghargaan finansial, pelatihan profesional, nilai-nilai sosial, lingkungan kerja, pertimbangan pasar kerja dan personalitas. Menurut Dalyono (1997:56) minat dalam pemilihan karir dapat timbul karena daya tarik dari luar dan juga datang dari hati nurani. Dengan kata lain minat dalam pemilihan karir dipengaruhi oleh dua faktor yaitu: (1) faktor yang berasal dari dalam diri mahasiswa misalnya emosional, persepsi, motivasi, dan kebutuhan, (2) faktor yang berasal dari luar diri mahasiswa misalnya lingkungan keluarga, sekolah, dan masyarakat.

Penghargaan finansial merupakan penghasilan yang diperoleh sebagai kontraprestasi dari pekerjaan yang telah dilakukan diyakini sebagian besar perusahaan sebagai daya tarik untuk memuaskan karyawannya dan mengungkapkan bahwa penghargaan finansial atau gaji merupakan faktor yang dipertimbangkan mahasiswa dalam memilih profesi (Wijayanti, 2001). Menurut Haswell dan Holmes (1988) serta Horowita dan Riley (1990) dalam Septiyani (2005) adanya gaji awal yang lebih tinggi dan jaminan dana pensiun di hari tua yang lebih baik menjadi faktor-faktor yang menjadi pertimbangan mahasiswa akuntansi dalam memilih karir sebagai auditor di instansi pemerintah. Penelitian septiyani (2005) menunjukan bahwa penghargaan finansial berpengauh signfikan terhadap pemilihan karir mahasiswa sebagai auditor pada instansi pemerintah.

Hasil penelitian yang dilakukan oleh Rahayu (2003) menunjukan bahwa mahasiswa yang memilih profesi akuntan publik dan akuntan perusahaan menganggap bahwa profesi yang mereka pilih lingkungan kerja memberikan banyak kesempatan untuk berkembang. Karir sebagai akuntan pemerintah pekerjaannya rutin yang rutinitasnya sedikit lebih tinggi dibanding akuntan perusahaan. Penelitian Widiatami (2013), menemukan bahwa lingkungan kerja berpengaruh terhadap pemilihan karir terha dap mahasiswa akuntansi.

Kepastian pasar kerja berhubungan erat dengan pekerjaan yang dapat diakses di masa yang akan datang. Pekerjaan yang memiliki pasar kerja yang lebih luas dan lebih pasti akan lebih diminati daripada pekerjaan yang pasar kerjanya kecil dan tidak adanya kepastian. Penelitian 
Aprilyan dan Laksito (2011), menemukan bahwa kepastian pasar kerja berpengaruh terhadap pemilihan karir menjadi akuntan publik.

Wijayanti (2001) mengungkapkan bahwa nilai-nilai sosial, dipertimbangkan oleh mahasiswa akuntansi dalam memilih profesi yang meliputi: kesempatan berinteraksi, kepuasan pribadi, kesempatan untuk menjalankan hobi, dan perhatian perilaku individu. Widiatami (2013) menemukan bahwa nilai-nilai sosial berpengaruh signifikan positif terhadap pemilihan karir hadap keberhasilan anak dalam keluarga. Penelitian Santoso (2014), menemukan bahwa lingkungan keluarga memiliki pengaruh signifikan positif terhadap pemelihan karir menjadi akuntan publik pada mahasiswa akuntasi.

Menurut Stolle (1970), pengakuan profesional dipertimbangkan oleh mahasiswa yang memilih profesi sebagai auditor di KAP maupun auditor internal perusahaan. Hal ini menunjukkan bahwa dalam memilih profesi tidak hanya mencari penghargaan finansial, tetapi juga ada keinginan untuk pengakuan berprestasi dan mengembangkan diri. Penelitian Lusi (2015), menemukan bahwa pengakuan profesianal berpengaruh secara statistik terhadap pemilihan karir menjadi auditor. Pemilihan karir tidak hanya dipengaruhi dari dalam diri mahasiswa itu sendiri, tetapi juga dipengaruhi dari luar seperti lingkungan keluarga. Menurut Djali (2012:99) situasi keluarga (ayah, ibu, adik, kakak, serta famili) sangat berpengaruh terhadap keberhasilan anak dalam keluarga. Penelitian Santoso (2014), menemukan bahwa lingkungan keluarga memiliki pengaruh signifikan positif terhadap pemelihan karir menjadi akuntan publik pada mahasiswa akuntasi.

Personalitas merupakan salah satu determinan yang potensial terhadap pelaku individu saat berhadapan dengan situasi/ kondisi tertentu. Hal ini membuktikan bahwa personalitas berpengaruh terhadap perilaku seseorang (Rahayu dkk, 2003). Dalam pemilihan karir sebagai akuntan publik dan non akuntan publik. hasil penelitian Aprilyan dan Laksito (2011) menyatakan bahwa variabel personalitas berpengaruh secara signifikan terhadap pemilihan karir sebagai akuntan publik. Berdasarkan uraian di atas, penulis tertarik untuk melakukan penelitian dengan judul "Faktor-Faktor Yang Mempengaruhi Mahasiswa Dalam Pemilihan Karir Menjadi Auditor pada Instansi Pemerintah dan Swasta"

\section{REVIEW LITERATUR DAN HIPOTESIS}

Teori Stakeholder (Stakeholder Theory)

Teori dasar konsep pemilihan karir yang digunakan sebagai landasan teori adalah teori pengharapan (Expectancy Theory). Definisi teori pengharapan adalah sifat dar manusia untuk bertindak sesuai harapan yang diingininya. Sedangkan, Abasara (2011) menyatakan kunci dari pengharapan adalah pemahaman sasaran individu dan keterkaitan antara upaya dan kinerja, antara kinerja dan imbalan

\section{Teori Hirarki kebutuhan Maslow}

Teori ini menyatakan bahwa meskipun tidak ada kebutuhan yang pernah dipenuhi secara lengkap, suatu kebutuhan yang dipuaskan secara subtansial tidak lagi memotivasi seseorang. Menurut Oktavia (2006) untuk memenuhi fisiologis, manusia harus bekerja atau berkarir sehingga mendapat gaji atau kompensasi lainnya yang dapat memenuhi kebutuhan tersebut. Selain itu juga membutuhkan rasa aman, penghargaan dan aktualisasi diri saat dia bekerja. 


\section{Auditor}

Auditor adalah seseorang yang memiliki kualifikasi tertentu dalam melakukan audit atas laporan keuangan dan kegiatan suatu perusahaan atau organisasi” (Wikipedia Bahasa Indonesia, 2017). Menurut Mulyadi dan Puradireja (1998), ada tiga golongan orang atau kelompok yang melaksanakan audit, ketiga golongan tersebut, yaitu:

1) Auditor Independen (KAP)

Auditor independen adalah auditor profesional yang menyediakan jasanya kepada masyarakat umum, terutama dalam bidang audit atas laporan keuangan yang dibuat oleh kliennya.

2) Auditor pemerintah

Auditor pemerintah adalah auditor yang bekerja untuk goverment accountability office (GAO) AS. Umumnya yang disebut sebagai auditor pemerintahan di Indonesia adalah auditor yang bekerja di Badan Pemeriksa Keuangan (BPK), Badan Pengawas Keuangan dan Pembangunan (BPKP), serta Inspektorat

3) Auditor intern (perusahaan)

Auditor internal adalah auditor yang bekerja dalam perusahaan tanpa mengikuti ujian sertifikasi dan tidak semua auditor internal perusahaan berasal dari jurusan akuntansi. Auditor internal memiiki fungsi mengawasi dan meninjau apakah prosedur yang diterapakan oleh manajemen telah dijalankan oleh semua jajaran perusaahn auditor internal tidak dapat di interpensi karna langsung melaporkan hasil kepada dewan direksi tanpa adanya perantara. Namun sering kali indepedensi auditor internal di pertanyakan karna merupakan bagian karyawan dari perusahaan tempat mereka bekerja.

\section{Karir}

Karir adalah urutan aktifitas-aktifitas yang berkaitan dengan pekerjaan dan perilaku-perilaku, nilai-nilai, dan aspirasi seseorangselama rentang hidup orang tersebut. Dalam pengembangan suatu karir menurut Kunartinah (2003), terdapat tahap-tahap yang dilalui oleh seseorang sebagai berikut:

1) Tahap pilihan karir (Career Choice)

Tahap pilihan karir secara umum terjadi antara masa remaja sampai umur 20 tahun, ketika manusia mengembangkan visi dan identitas mereka yang berkenaan dengan masa depan atau gaya hidup, sesuai dengan pilihan jurusan dan pendidikan seseorang.

2) Tahap karir awal (Early Career)

Selama periode tahap karir awal, seseorang juga meninjau kembali pengalaman yang terdahulu dan sekarang selama bekerja diperusahaan dan mencoba untuk menentukan sesuatu yang diharapkan di masa yang akan datang.

3) Tahap karir pertengahan (Middle Career)

Dalam tahap karir pertengahan ini, seseorang bergerak dalam suatu periode stabilisasi dimana mereka dianggap produktif, menjadi semakin lebih memikul tanggungjawab yang lebih berat dan menerapkan suatu rencana lahir yang lebih berjangka panjang.

4) Tahap karir akhir dan pensiun

Tahap karir akhir dan pensiun merupakan tahap terakhir dalam tahapan karir. Seseorang mulai melepaskan diri dari belitan-belitan tugasnya dan bersiap pensiun. Tahapan ini juga berguna untuk melatih penerus, mengurangi beban kerja atau mendelegasikan tanggung jawab kepada karyawan baru atau junior. 


\section{Pengembangan Hipotesis \\ Hubungan Penghargaan Finansial dengan Pemilihan Karir sebagai Auditor}

Penghasilan atau penghargaan finansial yang diperoleh sebagai kontraprestasi dari pekerjaan yang telah dilakukan dan diyakini sebagian besar perusahaan sebagai umpan balik untuk memuaskan karyawannya dan menyatakan penghargaan finansial adalah faktor yang dipertimbangkan mahasiswa dalam memilih profesi (Wijayanti, 2001). Penghargaan finansial yang baik dapat meningkatkan minat mahasiswa untuk memilih karir menjadi auditor.

H1: Penghargaan finansial berpengaruh terhadap pemilihan karir menjadi auditor

\section{Hubungan Lingkungan Kerja dengan Pemilihan Karir sebagai Auditor}

Lingkungan kerja merupakan suasana kerja yang meliputi sifat kerja (rutin, atraktif, dan sering lembur), tingkat persaingan antar karyawan dan tekanan kerja merupakan faktor dari lingkungan pekerjaan. Hasil penelitian yang dilakukan oleh Rahayu (2003) mengungkapkan bahwa mahasiswa yang memilih profesi akuntan publik dan akuntan perusahaan menganggap bahwa profesi yang mereka pilih akan memberikan banyak kesempatan untuk berkembang. Karir sebagai akuntan publik dianggap karir yang jenis pekerjaannya rutin, lebih atraktif dan banyak tantangannya, tidak dapat dengan cepat terselesaikan. Suatu lingkungan kerja yang baik akan mendorong minat mahasiswa dalam memilih karir menjadi auditor.

H2: Lingkungan kerja berpengaruh terhadap pemilihan karir menjadi auditor

\section{Hubungan Kepastian Pasar Kerja dengan Pemilihan Karir sebagai Auditor}

Kepastian kerja sangat erat hubungannya dengan akses pekerjaan yang dapat diakses dimasa depan. Seseorang cendrung memilih pekerjaan yang memiliki prospek kepastian kedepannya. Penelitian rahayu (2003) mengatkan mahasiswa akuntansi mempertimbangkan kepastian pasar kerja dalam menentukan karir sebagai akuntan publik maupun non akuntan publik.

H3: Kepastian pasar kerja berpengaruh terhadap pemilihan karir menjadi auditor

\section{Nilai-Nilai Sosial}

Rahayu (2003) mengatakan nilai sosial sangat dipertimbangakan oleh mahasiswa akuntansi universitas ngeri dan swasta dalam menentukan dan mempertimbangkan karirnya. Widiatami (2013) menemukan bahwa nilai-nilai sosial berpengaruh signifikan positif terhadap pemilihan karir mahasiswa akuntansi.

H4: Nilai-nilai sosial berpengaruh terhadap pemilihan karir menjadi auditor

\section{Pengakuan Profesional}

Penelitian Lusi (2015), menemukan bahwa pengakuan profesianal berpengaruh secara statistik terhadap pemilihan karir menjadi auditor. Zalmi (2017) menyatakan bahwa seseorang yang mempunyai niat bersungguh dalam berkarir tidak hanya mencari penghargaan finansial namun juga ingin diakui atas kinerja dan prestasinya yang telag diberikannya kepada perusahaan.

H5: Pengakuan professional berpengaruh terhadap pemilihan karir menjadi auditor

\section{Lingkungan Keluarga}

Pemilihan karir tidak hanya dipengaruhi dari dalam diri mahasiswa itu sendiri, tetapi juga dipengaruhi dari luar seperti lingkungan keluarga. Menurut Djali (2012:99) kondisi keluaraga dimana ibu, ayah dan saudara berpengaruh terhadap keberhasilan anak tersebut 
H6: Lingkungan Keluarga berpengaruh terhadap pemilihan karir menjadi auditor

\section{Personalitas}

Dalam pemilihan karir sebagai akuntan pubik dan non akuntan publik hasil penelitian Aprilyan dan Laksito (2011) menyatakan bahwa variabel personalitas berpengaruh secara signifikan terhadap pemilihan karir sebagai akuntan publik. Hasil penelitian ini didukung oleh hasil penelitian yang dilakukan oleh jumamik (2007). Berdasarkan penelitian tersebut dapat dihipotesiskan bahwa personalitas mempengaruhi mahasiswa dalam pemilihan karirnya.

H7: personalitas berpengaruh terhadap pemilihan karir menjadi auditor

\section{METODE PENELITIAN}

\section{Jenis Penelitian}

Berdasarkan rumusan masalah dan tujuan penelitian yang telah dijelaskan sebelumnya, maka jenis penelitian ini dikelompokan pada penelitian asosiasi kausatif (causative). Penelitian ini berusaha menjelaskan pengaruh penghargaan finansial $\left(\mathrm{X}_{1}\right)$, lingkungan kerja $\left(\mathrm{X}_{2}\right)$, kepastian pasar kerja $\left(\mathrm{X}_{3}\right)$, nilai-nilai sosial $\left(\mathrm{X}_{4}\right)$, pengakuan profosional $\left(\mathrm{X}_{5}\right)$, lingkungan keluarga $\left(\mathrm{X}_{6}\right)$, personalitas $\left(\mathrm{X}_{7}\right)$, sebagai variabel independen terhadap pemilihan karir menjadi auditor $(\mathrm{Y})$ sebagai variabel dependen.

\section{Populasi dan Sampel Penelitian}

Populasi yang digunakan dalam penelitian ini adalah mahasiswa akuntansi universitas negeri dan swasta se-Indonesia. Pengambilan sampel dilakukan dengan purposive sampling dengan kriteria yang ditentukan adalah mahasiswa akuntansi yang telah lulus mata kuliah auditing I dan auditing II.

\section{Jenis dan Sumber Data}

Dilihat dari cara memperolehnya data ini digolongkan pada data subjek. Data subjek (self report data) adalah jenis data penelitian yang berupa opini, sikap, pengalaman/karakteristik dari seorang/ sekelompok orang yang menjadi subjek penelitian (responden). Data yang digunakan adalah data primer yaitu data yang berasal dari kuesioner. Data primer adalah data yang secara langsung bersumber dari responden tanpa ada perantara, dalam hal ini adalah dari jawaban atas pertanyaan-pertanyaan yang ada dalam kuesioner. Data primer yang dihasilkan dalam penelitian ini adalah merupakan hasil dari tanggapan responden terhadap variabel-variabel penelitian yang akan diuji.

\section{Metode Pengumpulan Data}

Teknik pengumpulan data dalam penulisan proposal penelitian ini, digunakan dua cara penelitian:

\section{a. Studi kepustakaan}

Dilakukan untuk mengumpulkan data acuan, literatur-literatur dan buku-buku yang relevan untuk mendapatkan landasan teoritis yang akan digunakan sebagai bahan referensi dalam penelitian penulis. 


\section{b. Penelitian lapangan}

Data dikumpulkan menggunakan teknik kuesioner personal (personally administrated questionnaires). Responden diminta untuk mengisi kuesioner online lalu mengirimkannya dan secara otomatis data yang telah diisi masuk kedalam google drive peneliti.

\section{Analisis Data}

Uji Asumsi Klasik

1) Uji Normalitas

Uji normalitas residual dilakukan dengan menggunakan Kolmogorov-Smirnov test dengan taraf signifikan 5\%. Dasar pengambilan keputusan nilai $\mathrm{Sig} \geq 0,05$ maka dikatakan berdistribusi normal. Jika nilai Sig $<0,05$ maka dikatakan berdistribusi tidak normal.

\section{2) Uji heterokedastisitas}

Uji heterokedastisitas bertujuan untuk menguji apakah dalam model regresi terjadi ketidaksamaan varian dari residual satu pengamatan ke pengamatan yang lain (nilai errornya). Menguji ada atau tidaknya heteroskedastisitas maka penelitian ini melihat grafik scatterplots antara nilai prediksi terikat (dependen) yaitu ZPRED (Standardized Predicted Value) dengan residualnya SRESID (Standardized Residual). Jika ada pola tertentu, seperti titik yang ada membentuk pola tertentu yang teratur (bergelomang, melebar kemudian menyempit), maka mengindikasi telah terjadi heteroskedasitas. Jika tidak ada pola yang jelas, serta titik menyebar di atas dan di bawah angka 0 pada sumbu $\mathrm{Y}$, maka tidak terjadi heteroskedasitas.

\section{3) Uji Multikolenearitas}

Uji multikolinearitas bertujuan untuk menguji apakah model regresi ditemukan adanya korelasi antar variabel bebas atau indepenen. Pengujian ini dilakukan untuk melihat ada tidaknya hubungan linear antara variabel bebas yang dilakukan dengan menggunakan Variance Inflation Factor (VIF) dan tolerance value. Tolerance mengukur variabilitas variabel independenyang terpilih yang tidak dijelaskan oleh variabel independen lainnya, jadi nilai tolerance yang rendah samadengan nilai VIF yang tinggi. Nilai yang umum digunakan adalah tolerance value $>0.10$ atau samadengan nilai VIF $<10$. Jika tolerance value dibawah 0.10 atau nilai VIF diatas 10, maka terjadi multikolinearitas (Ghozalli, 2011)

\section{Teknik Analisis Data}

\section{Analisis Statistik Deskriptif}

Analisis statistik deskriptif digunakan untuk memberikan penjelasan dan gambaran umum demografi responden penelitian dan deskripsi mengenai variabel-variabel penelitian.

\section{a) Verifikasi data}

Verifikasi data yaitu memeriksa kembali kuesioner yang telah diisi oleh responden untuk memastikan apakah pertanyaan sudah diisi oleh responden.

\section{b) Menghitung nilai jawaban}

1. Menghitung frekuensi dari jawaban yang diberikan responden atas setiap item pertanyaan yang diajukan.

2. Menghitung rata-rata skor total item 
3. Menghitung nilai rata-rata jawaban responden dengan menggunakan rumus:

$$
\text { Mean }=\frac{\sum_{h=1}^{n} x_{i}}{n}
$$

Dimana :

$\mathrm{x}_{\mathrm{i}} \quad=$ Skor Total

$\mathrm{n} \quad=$ Jumlah Responden

4. Menghitung nilai TCR masing-masing kategori jawaban dari deskriptif variabel dengan menggunakan rumus:

$$
T C R=\frac{R_{g}}{n} x 100
$$

Dimana :

$$
\begin{array}{ll}
\mathrm{TCR} & =\text { Tingkat Capaian Responden } \\
\mathrm{R}_{\mathrm{S}} & =\text { Rata-rata Skor Jawaban Responden } \\
\mathrm{N} & =\text { Nilai Skor Jawaban }
\end{array}
$$

\section{Uji Kelayaan Model}

\section{a) Uji F (F-test)}

Uji statistik $\mathrm{F}$ pada dasarnya menunjukkan apakah semua variabel bebas dimasukkan dalam model mempunyai pengaruh secara bersama-sama terhadap variabel terikat. Nilai $\mathrm{F}$ statistik $\mathrm{F}$ dihitung dari formula sebagai berikut:

$$
\mathrm{F}=\frac{R^{2} / k}{\left(1-R^{2}\right) /(n-k-1)} \quad(\text { Irianto, 2004:207) }
$$

Jika $F_{\text {hitung }}>\mathrm{F}_{\text {tabel}}$, maka $\mathrm{H}_{0}$ ditolak, Jika $\mathrm{F}_{\text {hitung }}<\mathrm{F}_{\text {tabel}}$, maka $\mathrm{H}_{0}$ diterima dengan tingkat kepercayaan $(\alpha)$ untuk pengujian hipotesis adalah $95 \%$ atau $(\alpha)=0.05$.

\section{b) Uji Regresi Berganda}

Metode statistik yang digunakan untuk menguji hipotesis adalah regresi berganda (multiple regression analysis). Uji regresi berganda bertujuan untuk mengetahui pengaruh variabel independen terhadap variabel dependen maka digunakan model regresi berganda dengan persamaan sebagai berikut:

$$
\mathrm{Y}=\alpha+\beta 1 \mathrm{X} 1+\beta 2 \mathrm{X} 2+\beta 3 \mathrm{X3}+\beta 4 \mathrm{X} 4+\beta 5 \mathrm{X} 5+\beta 6 \mathrm{X} 6+\beta 7 \mathrm{X} 7+\mathrm{C}
$$

Keterangan :

$\mathrm{Y}=$ pemilihan karir menjadi auditor

$\alpha=$ Koefisien Intercept (konstanta)

$\beta=$ Koefisian Regresi

$\mathrm{X}_{1} \quad=$ Penghargaan Finasial

$\mathrm{X}_{2} \quad=$ Lingkungan Kerja

$\mathrm{X}_{3}=$ Kepastian Pasar Kerja

$\mathrm{X}_{4}=$ Nilai-Nilai Sosial

$\mathrm{X}_{5} \quad=$ Pengakuan Profesional 


$$
\begin{array}{ll}
\mathrm{X}_{6} & =\text { Lingkungan Keluarga } \\
\mathrm{X}_{7} & =\text { Personalitas } \\
\mathrm{e} & =\text { Error }
\end{array}
$$

\section{c) Uji Koefisien Determinasi $\left(\mathbf{R}^{\mathbf{2}}\right)$}

Untuk mengetahui kontribusi dari variabel bebas terhadap variabel terikat dilihat dari adjusted $R$ square-nya, pemilihan nilai adjusted $R$ square karena penelitian ini menggunakan analisis regresi berganda dengan jumlah variabel lebih dari satu. Koefisien determinasi $\left(R^{2}\right)$ pada intinya mengukur seberapa jauh kemampuan model dalam menerangkan variasi variabel terikat. Pengujian uji Koefisien Determinasi $\left(\mathrm{R}^{2}\right)$ menggunakan program SPSS versi 21.

\section{d) Uji T (T-Test)}

Uji statistik t pada dasarnya menunjukkan seberapa jauh pengaruh satu variabel penjelas secara individual dalam menerangkan variasi variabel terikat. Statistik $\mathrm{t}$ dihitung dari formula sebagai berikut:

$$
t_{k}=\frac{b_{k}}{S_{b k}} \quad \text { (Irianto, 2004:204) }
$$

Jika $\mathrm{t}_{\text {hitung }} \geq \mathrm{t}_{\text {tabel}}$, maka $\mathrm{H}_{0}$ ditolak, Jika $\mathrm{t}_{\text {hitung }}<\mathrm{t}_{\text {tabel }}$, maka $\mathrm{H}_{0}$ diterima dengan tingkat kepercayaan $(\alpha)$ untuk pengujian hipotesis adalah $95 \%$ atau $(\alpha)=0.05$.

\section{HASIL DAN PEMBAHASAN \\ Hasil Penelitian}

Jumlah sasaran sampel dalam penelitian ini adalah universitas negeri dan swasta yang ada di Indonesia. Seluruh sampel dalam penelitian ini yaitu mahasiswa akuntansi dari universitas negeri dan swasta yang ada di Indonesia dan menyebar kuisioner untuk penelitian dengan menggunakan google form. Kuisioner yang telah diisi responden sebanyak 310 responden seluruh indonesia, namun yang diolah sebesar 177 responden seluruh Indonesia yang berhubungan dengan pemilihan karir menjadi auditor.

\section{Uji Asumsi Klasik}

Uji asumsi klasik digunakan untuk mendeteksi ada atau tidaknya penyimpangan asumsi klasik atau persamaan regresi linear berganda yang digunakan. Pengujian ini terdiri atas uji normalitas, uji multikolinearitas dan uji heteroskedastisitas. Berikut hasilnya akan dijelaskan satu per satu.

\section{Uji Normalitas}

Alat uji normalitas yang digunakan untuk menguji data yang berdistribusi normal adalah One Sample Komogorov-Smirnov (KS). Pada pengujian normalitas menggunakan uji KolmogorvSmirnov. Jika nilai signifikansi > 0,05 maka Ho diterima (berdistribusi normal) sedangkan jika nilai signifikansi < 0,05 maka Ho ditolak (tidak berdistribusi normal) (Ghozali, 2016). 
Tabel 1

Uji Normalitas

One-Sample Kolmogorov-Smirnov Test

\begin{tabular}{|c|c|c|}
\hline & & $\begin{array}{l}\text { Unstandardized } \\
\text { Residual }\end{array}$ \\
\hline $\mathrm{N}$ & & 177 \\
\hline \multirow[t]{2}{*}{ Normal Parameters ${ }^{\mathrm{a}, \mathrm{b}}$} & Mean &, 0000000 \\
\hline & Std. Deviation & 5,41987176 \\
\hline \multirow[t]{3}{*}{ Most Extreme Differences } & Absolute &, 075 \\
\hline & Positive &, 053 \\
\hline & Negative &,- 075 \\
\hline Test Statistic & &, 075 \\
\hline Asymp. Sig. (2-tailed) & &, $017^{\mathrm{c}}$ \\
\hline
\end{tabular}

Berdasarkan hasil analisis metode One Sample Kolmogorov-Smirnov pada tabel 4.14 diatas, menunjukkan bahwa nilai Kolmogorov-Smirnov adalah sebesar 0,075 dan nilai signifikan 0,017 $<0,05$, ini berarti bahwa data tidak terdistribusi secara normal. Gujarati (2006) menyatakan bahwa, uji normalitas tidak terlalu diperhatikan secara penting ketika sebuah penelitian memiliki jumlah set data yang besar, yaitu lebih dari 30. Penelitian ini memiliki jumlah data lebih dari 30 sehingga asumsi klasik normalitas tidak terlalu dipermasalahkan.

\section{Uji moltikolorienitas}

Multi kolonieritas bertujuan untuk menguji apakah adanya korelasi antar variabel bebas atau independent dalam model regresi. Untuk mendeteksi adanya masalah multikolonieritas dalam penelitian ini dengan menggunakan nilai Tolerance dan Variance Inflation Factor (VIF). Regresi yang terbebas dari masalah multikolonieritas apabila $V I F<10$ dan nilai Tolerance $>0.10$ maka data tersebut tidak Multikolonieritas (Ghozali, 2016).

Tabel 2

Uji Multikolorienitas

\begin{tabular}{ccc}
\hline \multicolumn{3}{c}{ Coefficients $^{\mathbf{a}}$} \\
\cline { 2 - 2 } Model & \multicolumn{2}{c}{ Collinearity Statistics } \\
\cline { 2 - 3 } & Tolerance & VIF \\
\hline (Constant) & & \\
\hline $\mathrm{X} 1$ & 0,25 & 3,996 \\
\hline $\mathrm{X} 2$ & 0,301 & 3,324 \\
\hline $\mathrm{X} 3$ & 0,412 & 2,428 \\
\hline $\mathrm{X} 4$ & 0,23 & 4,348 \\
\hline $\mathrm{X} 5$ & 0,256 & 3,912 \\
\hline $\mathrm{X} 6$ & 0,389 & 2,571 \\
\hline X7 & 0,286 & 3,499 \\
\hline a. Dependent Variable: $\mathrm{Y}$ \\
\hline
\end{tabular}


Dari hasil output diatas, hasil perhitungan nilai tolerance setiap variabel lebih besar dari 0,10 dan nilai VIF setiap variabel kurang dari 10. Kesimpulannya maka data tersebut tidak multikolonieritas.

\section{Uji Heteroskedastisitas}

Uji heterokedastisitas bertujuan untuk menguji apakah dalam model regresi terjadi ketidaksamaan varian dari residual satu pengamatan ke pengamatan yang lain (nilai errornya). Dalam penelitian, pengujian heterokedastisitas dilakukan dengan melihat pola titik-titik pada grafik regeresi antara nilai prediksi variabel terikat (dependen) yaitu ZPRED (Standardized Predicted Value) dengan residualnya SRESID (Standardized Residual). Uji yang baik seharusnya tidak terjadi heterokedastisitas. Pada hasil pengolahan data didapatkan grafik regresi scatterplot sebagai berikut:

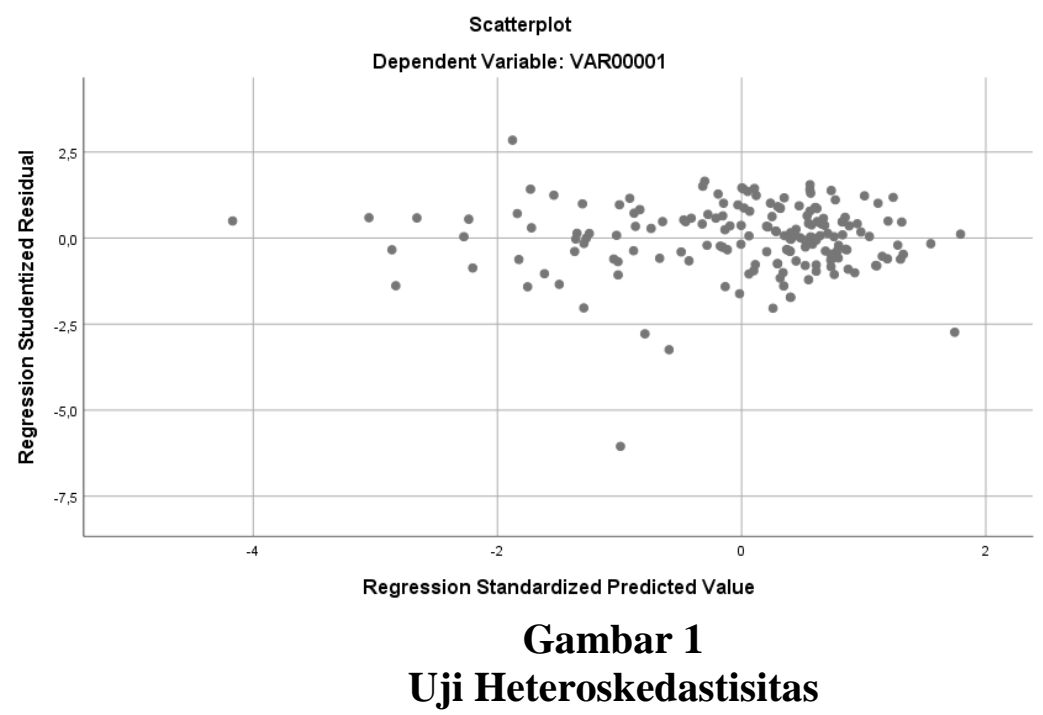

Gambar di atas menunnjukkan tidak terdapat pola tertentu pada grafik scatterplot antara SRESID dan ZPRED dimana sumbu Y adalah residual (Y prediksi-Y sesungguhnya) yang telah distandardized. Jadi tidak ada pola yang jelas, serta titik menyebar di atas dan di bawah angka 0 pada sumbu Y, maka dapat disimpulkan tidak terjadi heterokedastisitas dan layak untuk diteliti.

\section{Uji Kelayakan Model}

\section{Koefesien determinasi $\left(\mathrm{R}^{2}\right)$}

Merupakan alat yang digunakan untuk mengukur seberapa jauh kemampuan model dalam menerangkan variasi variabel dependen. Nilai koefisien determinasi antara nol dan satu. Semakin nilai $\mathrm{R}^{2}$ mendekati satu maka variabel - variabel independen memberikan hampir semua informasi yang dibutuhkan untuk memprediksi variabel - variabel dependen (Ghozali, 2016). 


\section{Tabel 3}

\section{Uji Koefisien Determinasi}

Model Summary ${ }^{b}$

\begin{tabular}{lcrrrr}
\hline Model & $\mathrm{R}$ & $\mathrm{R}$ Square & $\begin{array}{c}\text { Adjusted R } \\
\text { Square }\end{array}$ & $\begin{array}{c}\text { Std. Error of the } \\
\text { Estimate }\end{array}$ & Durbin-Watson \\
\hline 1 &, $884^{\mathrm{a}}$ &, 781 &, 772 & 5,53098 & 1,909 \\
\hline $\begin{array}{l}\text { a. Predictors: (Constant), X1, X2, X3, X4, X5, X6, X7 } \\
\text { b. Dependent Variable: Y }\end{array}$
\end{tabular}

Dari hasil output diatas mennjukkan besarnya nilai Adjusted $\mathrm{R}^{2}$ adalah 0,772 atau 77,2\% variasi pemilihan karir menjadi auditor dapat dijelaskan oleh variasi dari ketujuh variabel independen penghargaan finansial, lingkungan kerja, kepastian pasar kerja, nilai-nilai sosial, pengakuan profesional, lingkungan keluarga, dan personalitas. Sedangkan sisanya (100\% $77,2 \%=27,8 \%$ ) dijelaskan oleh variabel lain diluar dari variable penelitian ini.

\section{Uji F}

\section{Tabel 4}

Uji F

ANOVA $^{\mathrm{a}}$

\begin{tabular}{llrrrrr}
\hline Model & & Sum of Squares & Df & Mean Square & F & \multicolumn{1}{l}{ Sig. } \\
\hline 1 & Regression & 18399,637 & 7 & 2628,520 & 85,923 &, $000^{\mathrm{b}}$ \\
\cline { 2 - 7 } & Residual & 5170,002 & 169 & 30,592 & & \\
\cline { 2 - 7 } & Total & 23569,638 & 176 & & & \\
\hline
\end{tabular}

a. Dependent Variable: Y

b. Predictors: (Constant), X1,X2,X3,X4,X5,X6,X7

Berdasarkan tabel diatas, diketahui $F_{\text {hitung }}$ sebesar 85,923 $>F_{\text {tabel }}$ sebesar 2,064 dengan signifikansi $0,000<0,05$. sehingga dapat disimpulkan bahwa penghargaan finansial, lingkungan kerja, kepastian pasar kerja, nilai-nilai social, pengakuan profesional lingkungan keluarga, dan personalitas berpengaruh signifikan secara simultan (bersama-sama) terhadap pemilihan karir menjadi auditor serta persamaan regresi yang digunakan dalam penelitian ini dapat diandalkan atau model sudah fix.

\section{Analisis regresi berganda}

Tujuan dari analisis regresi linear berganda untuk mengetahui apakah variabel independen berhubungan positif atau negatif terhadap variabel dependen. Dari hasil output dibawah ini dapat dilihat persamaan regresi linear berganda seperti berikut.

\section{a. Koefisien Regresi ( $\beta$ ) $\mathrm{X}_{3}$}

Nilai koefisien regresi variabel kepastian pasar kerja sebesar 0,519 . Hal ini menunjukkan bahwa setiap peningkatan satu satuan tingkat kepastian pasar kerja akan mengakibatkan peningkatan pemilihan karir menjadi auditor sebesar 0,519 dengan anggapan variabel bebas lainnya tetap. 


\section{b. Koefisien Regresi ( $\beta) \mathrm{X}_{4}$}

Nilai koefisien regresi variabel nilai-nilai sosial sebesar 0,180. Hal ini menunjukkan bahwa setiap peningkatan satu satuan tingkat nilai-nilai sosial akan mengakibatkan peningkatan pemilihan karir menjadi auditor sebesar 0,180 dengan anggapan variabel bebas lainnya tetap.

c. Koefisien Regresi ( $\beta$ ) $\mathrm{X}_{5}$

Nilai koefisien regresi variabel pengakuan profesional sebesar 0,127 . Hal ini menunjukkan bahwa setiap peningkatan satu satuan tingkat pengakuan profesional akan mengakibatkan peningkatan pemilihan karir menjadi auditor sebesar 0,127 dengan anggapan variabel bebas lainnya tetap.

\section{d. Koefisien Regresi $(\beta) X_{6}$}

Nilai koefisien regresi variabel lingkungan keluarga sebesar 0,075. Hal ini menunjukkan bahwa setiap peningkatan satu satuan tingkat lingkungan keluarga akan mengakibatkan peningkatan pemilihan karir menjadi auditor sebesar 0,075 dengan anggapan variabel bebas lainnya tetap.

e. Koefisien Regresi ( $\beta$ ) $\mathrm{X}_{7}$

Nilai koefisien regresi variabel personalitas sebesar 0,857 . Hal ini menunjukkan bahwa setiap peningkatan satu satuan tingkat personalitas akan mengakibatkan peningkatan pemilihan karir menjadi auditor sebesar 0,857 dengan anggapan variabel bebas lainnya tetap.

Tabel 5

Analisis regresi berganda Coefficients $^{\mathrm{a}}$

\begin{tabular}{|c|c|c|c|c|c|c|c|}
\hline \multirow[b]{2}{*}{ Model } & \multicolumn{2}{|c|}{$\begin{array}{c}\text { Unstandardized } \\
\text { Coefficients }\end{array}$} & $\begin{array}{l}\text { Standardized } \\
\text { Coefficients }\end{array}$ & \multirow[b]{2}{*}{$\mathrm{t}$} & \multirow[b]{2}{*}{ Sig. } & \multicolumn{2}{|c|}{$\begin{array}{c}\text { Collinearity } \\
\text { Statistics }\end{array}$} \\
\hline & B & $\begin{array}{l}\text { Std. } \\
\text { Error }\end{array}$ & Beta & & & Tolerance & VIF \\
\hline 1 (Constant) &,- 581 & 2,691 & &,- 216 & ,829 & & \\
\hline $\bar{X} 1$ & ,605 &, 141 & ,308 & 4,280 & ,000 & ,250 & 3,996 \\
\hline $\mathrm{X} 2$ & ,243 &, 150 & ,106 & 1,615 & ,108 & ,301 & 3,324 \\
\hline $\mathrm{X} 3$ &, 519 &, 143 & ,204 & 3,631 & $\overline{, 000}$ & ,412 & 2,428 \\
\hline $\mathrm{X} 4$ &, 180 & , 198 & ,068 & ,908 & ,365 & ,230 & 4,348 \\
\hline $\mathrm{X} 5$ &, 127 & ,213 &, 043 & ,597 &, 552 & ,256 & 3,912 \\
\hline $\mathrm{X} 6$ & ,075 & , 109 & ,040 & ,686 & ,493 & ,389 & 2,571 \\
\hline$\overline{X 7}$ & ,857 & ,247 & ,234 & 3,476 & ,001 & ,286 & 3,499 \\
\hline
\end{tabular}

\section{Uji T}

Pengujian ini bertujuan untuk mengetahui seberapa jauh pengaruh satu variabel independen secara individual dalam menerangkan variasi variabel dependen (Ghozali, 2016). Kriteria penerimaan dan penolakan hipotesis adalah jika $t_{\text {hitung }}>t_{\text {tabel, }}$, maka Ha diterima (ada pengaruh signifikan). Jika thitung $<t_{\text {tabel}}$, maka Ha ditolak(tidak ada pengaruh). Berdasarkan dasar signifikansi, kriterianya adalah jika signifikansi > 0,05 maka Ha ditolak, jika signifikansi < 0,05 maka Ha diterima (Idris, 2014:54). 


\section{Pengujian Hipotesis Pertama $\left(\mathbf{H}_{1}\right)$}

Variabel pengungkapan media pada tabel 4.17 memiliki nilai thitung $4,280>t_{\text {tabel }} 1,974$ dan nilai sig $(0,000)<\alpha(0,05)$ serta nilai koefisien $\beta$ sebesar 0,605 . Hal ini menunjukkan bahwa variable penghargaan finansial berpengaruh positif terhadap pemilihan karir menjadi auditor, sehingga dapat disimpulkan bahwa Hipotesis 1 diterima.

\section{Pengujian Hipotesis Kedua $\left(\mathbf{H}_{2}\right)$}

Variabel lingkungan kerja pada tabel 4.17 memiliki nilai $t_{\text {hitung }} 1,615<\mathrm{t}_{\text {tabel }} 1,974$ dan nilai sig $(0,108)>\alpha(0,05)$. Hal ini menunjukkan bahwa variabel limgkungan kerja tidak berpengaruh positif terhadap pemilihan karir menjadi auditor, sehingga dapat disimpulkan bahwa Hipotesis 2 ditolak.

\section{Pengujian Hipotesis ketiga $\left(\mathrm{H}_{3}\right)$}

Variabel kepastian pasar kerja pada tabel 4.17 memiliki nilai thitung $3,631>t_{\text {tabel }} 1,974$ dan nilai $\operatorname{sig}(0,000)<\alpha(0,05)$. Hal ini menunjukkan bahwa variabel kepastian pasar kerja berpengaruh positif terhadap pemilihan karir menjadi auditor, sehingga dapat disimpulkan bahwa Hipotesis 3 diterima.

\section{Pengujian Hipotesis Keempat $\left(\mathrm{H}_{4}\right)$}

Variabel nilai-nilai sosial pada tabel 4.17 memiliki nilai thitung $0,908<t_{\text {tabel }} 1,974$ dan nilai sig $(0,365)>\alpha(0,05)$. Hal ini menunjukkan bahwa variabel nilai-nilai social tidak berpengaruh positif terhadap pemilihan karir menjadi auditor, sehingga dapat disimpulkan bahwa Hipotesis 4 ditolak.

\section{Pengujian Hipotesis Kelima $\left(\mathbf{H}_{5}\right)$}

Variabel pengakuan presional pada tabel 4.17 memiliki nilai thitung $0,597<\mathrm{t}_{\text {tabel }} 1,974$ dan nilai sig $(0,552)>\alpha(0,05)$. Hal ini menunjukkan bahwa variabel pengakuan professional tidak berpengaruh positif terhadap pemilihan karir menjadi auditor, sehingga dapat disimpulkan bahwa Hipotesis 5 ditolak.

\section{Pengujian Hipotesis Keenam (H6)}

Variabel lingkungan keluarga pada tabel 4.17 memiliki nilai thitung $0,686<\mathrm{t}_{\text {tabel }} 1,974$ dan nilai sig $(0,493)>\alpha(0,05)$. Hal ini menunjukkan bahwa variable lingkungan keluarga tidak berpengaruh positif terhadap pemihan karir menjadi auditor, sehingga dapat disimpulkan bahwa Hipotesis 6 ditolak.

\section{Pengujian Hipotesis Ketujuh $\left(\mathrm{H}_{7}\right)$}

Variabel personalitas pada tabel 4.17 memiliki nilai thitung 3,476 > tabel 1,974 dan nilai sig $(0,001)<\alpha(0,05)$. Hal ini menunjukkan bahwa variabel personalitas berpengaruh positif terhadap pemilihan karir menjadi auditor, sehingga dapat disimpulkan bahwa Hipotesis 7 diterima. 


\section{Pembahasan \\ Pengaruh Penghargaan Finansial Terhadap Pemilihan Karir Menjadi Auditor}

Berdasarkan hasil analisis statistik dalam penelitian terhadap mahasiswa akuntansi seIndonesia dinyatakan bahwa hipotesis 1 diterima. Melalui analisis yang dilakukan, didapatkan penghargaan finansial berpengaruh positif terhadap pemilihan karir menjadi auditor. Hasil yang diperoleh dalam penelitian ini menunjukan penghargaan finansial berpengaruh terhadap pemilihan karir menjadi auditor.

Hasil penelitian ini sejalan konsisten dengan hasil lusi (2015) yang menyatakan faktor penghargaan finansial memiliki pengaruh yang signifikan terhadap pemilihan karir menjadi auditor pada instansi pemerintah dan swasta. Hasil tersebut bisa menjelaskan bahwa penghrgan finansial bisa mempengaruhi mahasiswa dalam pemilihan karirnya untuk menjadi auditor. Mahasiswa akuntansi ingin menjadi auditor mengharapkan gaji yang adil yaitu sesuai dengan pengorbanan yang dilakukan serta layak dan wajar yaitu sesuai dengan standar pemenuhan kebutuhan hidup dan memperoleh penghargaan finansial langsung maupun tidak langsung. Teori dari Maslow yaitu kebutuhan fisiologis, dalam hubungannya dengan penghargan finansial manusia membutuhkan penghargaan finansial untuk memenuhi kebutuhan dasarnya seperti makan, minum, dan tempat tinggal. Menurut Oktavia (2006) untuk memenuhi fisiologis, manusia harus bekerja atau berkarir sehingga mendapat gaji atau kompensasi lainnya yang dapat memenuhi kebutuhan tersebut.

\section{Pengaruh Lingkungan Kerja Terhadap Pemilihan Karir Menjadi Auditor}

Berdasarkan hasil analisis statistik dalam penelitian ini dinyatakan bahwa hipotesis 2 ditolak. Melalui pengujian regresi berganda, didapatkan lingkungan kerja tidak berpengaruh positif terhadap pemilihan karir menjadi auditor. Lingkungan kerja ditandai dengan pekerjaan yang rutin, pekerjaan lebih cepat diselesaikan, pekerjaannya lebih antraktif atau banyak tantangan, lingkungan kerjanya menyenangkan, sering lembur, tingkat kompetisi antar karyawan tinggi dan ada tekanan untuk mencapai hasil yang sempurna tidak berpengaruh positif terhadap pemilihan karir menjadi auditor. Artinya, jika lingkungan kerja meningkat atau menurun tidak akan mempengaruhi dalam pemilihan karir mahasiswa menjadi auditor

Dalam hal ini menandakan bahwa mahasiswa dalam pemilihan karirnya tidak mempertimbangkan faktor lingkungan kerja yan akan mereka hadapi nantinya sehingga menyebabkan ketidaksesuain. Bagai mahasiswa fresh graduate yang sama sekali belum berpengalaman dalam dunia kerja, tujuan utamanya mereka setelah lulus adalah ingin cepat memperoleh pekerjaan lalu memperoleh penghasilan yang mencukupi, dan mendapatkan posisi atau jabatan yang berprospektive. Berdasarkan penilitian terdahulu, maka hasil penelitian ini seiiring dengan penelitian Ramadani (2013), dimana hasil penelitian menunjukan bahwa variabel lingkungan kerja tidak berpengaruh positif terhadap pemilihan karir mahasiswa akuntansi.

\section{Pengaruh Kepastian Pasar Kerja Terhadap Pemilihan Karir Menjadi Auditor}

Berdasarkan hasil statistik dalam penelitian ini dinyatakan bahwa hipotesis 3 diterima. Melalui pengujian regresi berganda, didapatkan kepastian pasar kerja berpengaruh positif terhadap pemilihan karir menjadi auditor. Hasil yang diperoleh dalam penilitian ini menunjukan kepastian pasar kerja berpengaruh positif terhadap pemilihan karir menjadi 
auditor. Artinya pemilihan karir menjadi auditor akan meningkat seiring dengan meningkatknya kepastian pasar kerja.

Jika diliat dari hasil penelitian terdahulu, maka hasil penelitian ini sejalan dengan penelitian harianti (2017), dimana hasil peneilitian ini menunjukan bahwa kepastian pasar kerja berpengaruh positif terhadap minat menjadi akuntan publik. Hasil penelitian ini juga konsisten dengan sosioeconomic theory kondisi ekonomi seperti peluang pekerjaan atau pasar kerja, jumlah gaji, dan sejenisnya berdampak pada pilihan karir mahasiswa. Hasil tersebut mampu membuktikan bahwa kepastian pasar kerja merupakan salah satu variabel penting yang mempengaruhi mahasiswa dalam pemilhan karir menjadi auditor. Mahasiswa akuntansi dalam memilih profesi yang akan digelutinya nanti mempertimbangkan tersedianya lapangan pekerjaan terkait persaingan pasar kerja yang semakin ketat. Jika kepastian pasar kerja profesi auditor lebih baik dibandingkan dengan profesi lainnya, maka minta mahasiswa auntansi untuk menjadi auditor pun akan semakin tinggi.

\section{Pengaruh Nilai-Nilai Sosial Terhadap Pemilihan Karir Menjadi Auditor}

Berdasarkan hasil analisis statistik dalam penelitian ini dinyatakan bahwa hipotesis 4 ditolak. Melalui pengujian regresi berganda, didapatkan nilai-nilai sosial tidak berpengaruh positif terhadap pemilihan karir menjadi auditor.Dapat disimpulkan bahwa adanya kesempatan untuk melakukan kegiatan sosial, berinteraksi dengan orang lain dan menjalankan hobi tidak akan mempengaruhi mahasiswa akuntansi untuk memilih berkarir menjadi auditor. Dikarenakan responden memiliki pandangan bahwa seseorang yang akan berkarir nantinya akan ditugaskan diberbagai tempat dan disetiap perusahan atau instansi pemerintah cenderung memiliki kondisi yang berbeda-beda. Hasil penelitian ini sejalan dengan penelitian yang dilakukan Zalmi (2017) dimana nilai-nilai sosial tidak mempengaruhi mahasiswa akuntansi dalam pemilihan karinya sebagai auditor.

\section{Pengaruh Pengakuan Profesional Tehadap Pemilihan Karir Menjadi Auditor}

Berdasarkan hasil analisis statistik dalam penelitian ini dinyatakan bahwa hipotesis 5 ditolak. Hasil penelitian ini sejalan dengan penelitian terdahulu Al Hadar (2013), dimana hasil penelitian ini menunjukan bahwa pengakuan profesional tidak dipertimbangkan oleh mahasiswa akuntansi dalam menentukan karirnya sebagai auditor baik pada intansi pmerintah maupun swasta. Dalam menentukan karir atau jenis pekerjaan mendapatkan pengakuan profesionalitas tidak hanya menjadi auditor.

Muhajir hakim (2017), dalam kutipannya mengatakan seorang auditor lebih mengutamakan peran profesionalnya dari pada pengakuan profesional. Ada empat peran profesional seorang auditor yaitu menjamin kualitas informasi yang diungkapkan dalam laporang keuangan, bertindak sebagai pihak yang independen dan kompeten dalam melakukan audit, membantu dalam menjaga dan menegakkan GCG perusahaan, serta bertanggung jawab dalam pencegahan, pendeteksian, dan investigasi dalam berbagai bentuk kecurangan.

\section{Pengaruh Lingkungan Keluarga Terhadap Pemilihan Karir Menjadi Auditor}

Berdasarkan hasil analisis statistik dalam penelitian ini dinyatakan bahwa hipotesis 6 ditolak. Melalui pengujian regresi berganda, didapatkan lingkungan keluarga tidak berpengaruh positif terhadap pemilihan karir menjadi auditor. Secara mendalam dapat diketahui lingkungan keluarga berupa perhatian orang tua, dorongan orang tua, dan profesi yang ada dalam keluarga 
tidak berpengaruh terhadap pemilihan karir menjadi auditor. Artinya, jika lingkungan keluarga meningkat atau menurun tidak akan mempengaruhi mahasiswa dalam menentukan karirnya sebagai auditor.

Berdasarkan penelitian terdahulu, maka hasil penelitian ini sejalan dengan penelitian Putra (2017) dimana lingkungan keluarga tidak mempengaruhi mahasiswa dalam pemilihan karirnya menjadi auditor. Jika ditinjau dari aspek teoritis maka ini bertentangan dengan teori yang ada. Sebagaimana menurut Dalyono (1997) menyatakan bahwa minat dalam menentuakan karir timbul karena daya tarik dari luar, salah satunya lingkungan keluarga. Hal ini membuktikan bahwa dengan tingginya perhatian dan dukungan orang tua belum tentu menyebabkan mahasiswa akuntansi mempertimbangkan pekerjaan orang tuanya saat ini jika berminat menjadi auditor. Begitupun ketika ada salah satu angota keluarga yang berprofesi sebagai auditor, hal demikian belum tentu mahasiswa akuntansi melakukan hak yang serupa. Socioeconoic theori mengatakan bahwa kondisi sosial seperti orang tua, teman, guru atau dosen, status sosial dan kondisi ekonomi seperti, peluang pekerjaan, jumlah gaji, dan sejenisnya berdampak dalam pemilihan karir mahasiswa (Venable dalam Dibabe et al, 2015).

\section{Pengaruh Personalitas Terhadap Pemilihan Karir Mejadi Auditor}

Berdasarkan hasil analisis statistik dalam penelitian ini dinyatakan bahwa hipotesis 7 diterima. Melalui pengujian regresi berganda, personalitas berpengaruh positif terhadap pemilihan karir menjadi auditor. Hasil penelitian ini sejalan dengan hasil penelitian Rahayu (2003), dimana persoanlitas berpengaruh signikan terhadap pemilihan karir mahasiswa untuk menjadi akun publik dan non akuntan publik. Rahayu dkk (2003) mengatakan bahwa, personalitas merupakan salah satu determinan yang potensial terhadap perilaku individu saat berhadapan dengan situasi atau kondisi tertentu.

Djuwita dalam Masli dkk (2006) mengatakan bahwa faktor penyebab seseorang kehilangan pekerjaan antara lain karena ketidaksesuaian kepribadian mereka dengan pekerjaan. Profesi auditor tidak hanya harus memiliki keahlian, tetapi harus diimbangi dengan skeptisme profesional. Sikap tersebut diatur dalam kode etik profesi akuntan publik diaantaranya independen, integritas dan obyektifitas, jujur atas semua temuan yang dilakukan selama proses audit, menjaga informasi rahasia atas kliennya.

\section{DAFTAR PUSTAKA}

Chan, A. S. (2012). Analisis Faktor-Faktor Yang Mempengaruhi Pemilihan Karir Menjadi Akuntan Publik Oleh Mahasiswa Jurusan Akuntansi. Jurnal Ilmiah Mahasiswa Akuntansi, 1(1): 53-58.

Felton, S., Buhr, N. and Northey, M. (1994). Factors Influencing the Business Student's Choice of a Career in Chartered Accountancy. Issues in Accounting Education

Ghozali, I. (2005). Aplikasi Analisis Multivariate Dengan Program SPSS. Semarang: Badan Penerbit Universitas Diponegoro

Greenberg, J. and Baron, R. A. (2000). Behavior in Organization. Understanding and Managing the Human Side of Work, Upper Saddle

Harianti, S. S. (2017). Pengaruh Penghargaan finansial Pertimbangan Pasar Kerja dan Lingkungan Keluarga terhadap Minat Menjadi Akuntan Publik. Skripsi. Universitas Negeri Padang. Padang. 
Hasibuan, M. S. P. (2003). Manajemen Sumber Daya Manusia, Edisi Revisi, Cetakan Keenam. Jakarta: PT. Bumi Aksara

https://id.wikipedia.org/wiki /Auditor

Lusi. (2015). Faktor-Faktor Yang Mempengaruhi Mahasiswa Akuntansi Fakultas Ekonomi Dan Bisnis Universitas Sumatera Utara Dalam Pemilihan Karir Menjadi Auditor Pada Instansi

Swasta Dan Pemerintah. Skripsi. Fakultas Ekonomi dan Bisnis Universitas Sumatera Utara

Mulyadi \& Puradireja, K. (1998). Auditing. Edisi kelima. Jakarta: Penerbit Salemba Empat.

Mulyadi dan Puradiredja, K. (1998). Auditing (edisi kelima). Jakarta: Salemba Empat

Mulyadi. (2002). Auditing. Edisi Keenam. Jakarta: Penerbit Salemba Empat

Nadlari, M. T. J. (2015). Presepsi Mahasiswa Akuntansi Mengenai Faktor-Faktor yang Membedakan Pemilihan Karir. Skripsi. Universitas Pendidikan Ganesha

Rahayu, S. dkk. (2003). Presepsi Mahasiswa Akuntansi Mengenai Faktor-Faktor yang Mempengaruhi Karir. Simposium Nasional Akuntansi IV. 16-17 Oktober 2003. Surabaya.

Rahayuningsih, D. A. (2002). Harapan dan Kenyataan dalam Berkarier di Kantor Akuntan Publik: Suatu Perbandingan Antara Mahasiswa Akuntansi dan Auditor. Jurnal Bisnis dan Akuntansi, 4(3)

Ramdani, R. F. (2013). Analisis Faktor-Faktor yang Mempengaruhi Penilian Karir Mahasiswa Akuntansi. Skripsi. Universitas Diponegoro

Rasmini, N. K. (2007). Faktor-Faktor yang Berpengaruh pada Keputusan Pemilihan Profesi Akuntan Publik dan Non Akuntan Publik pada Mahasiswa Akuntansi di Bali. Buletin Studi Ekonomi, 12(3): 351 - 366.

Rivai, V. (2006). Manajemen Sumber Daya Manusia Untuk Perusahaan: Dari Teori ke Praktik, Edisi Pertama. Jakarta: PT. RajaGrafindo Persada

Sekaran, U. (2006). Research Methods for Business. Metodologi Penelitian Untuk Bisnis Edisi Empat, Buku Satu. Jakarta: Salemba Empat

Stolle, S.D. (1976). Student's View of The Public and Industrial Accountant. Jurnal of Accountancy

Sugiyono. (1999). Metode Penelitan Bisnis, Cetakan Ke-6. Bandung: CV. Alfa Beta.

Sugiyono. (2008). Metode Penelitian Pendidikan Pendekatan Kuantitatif, Kualitatif dan R\&D. Bandung: Alfabeta

Undang-Undang Republik Indonesia Nomor 5 tahun 2011 tentang Akuntan Publik.

Wahjosumidjo. (1987). Kepemimpinan dan Motivasi, Jakarta: Ghalia.

Wijayanti. (2003). Faktor-Faktor yang Mempengaruhi Pemilihan Karir Mahasiswa Akuntansi di Yogyakarta. Jurnal Riset Akuntansi Indonesia, 3(2): 13 - 26

Wijiyanti. (2001). Faktor-Faktor yang Mempengaruhi Pilihan Karir Mahasiswa Akuntansi. Tesis. Universitas Gadjah Mada 